\title{
AVOIDING CAVERNS IN THE ARBUCKLE MOUNTAINS USING ELECTRICAL IMAGING METHODS
}

\author{
Peter J. Hutchinson \\ THG Geophysics, Ltd., 4280 Old Wm. Penn Hwy., Murrysville, Pennsylvania, 15668,USA, pjh@thggeophysics.com
}

\begin{abstract}
The Arbuckle Mountains in Oklahoma are a unique province with nearly vertical dipping beds of the Upper Cambrian to Lower Ordovician Arbuckle Group. The Arbuckle Group consists of intercalated sequences of thick carbonates and thinner shales and sandstones. SynPennsylvanian mountain building steeply tilted these beds. Subsequently, caves and voids developed within the carbonate beds, presumably by hypogene speleogenesis.
\end{abstract}

Numerous dissolution cavities and several major cave systems have been mapped within the Arbuckle Mountain Wind Farm located $19 \mathrm{~km}$ north of Ardmore, Oklahoma. Electrical resistivity imaging was determined to be the most effective method of mapping subsurface voids and caverns due to the strong electrical contrast between carbonate units and void-filling sediments and groundwater.

Electrical resistivity imaging during early stages of the wind farm development identified numerous caverns and voids beneath proposed turbine sites; consequently, several wind tower locations were moved. This report addresses the East Access Road to six proposed turbine wind tower sites where three towers and access road near the towers were relocated south of their original proposed locations. Further, the Main Access Road to these six tower sites had to be rerouted due to the presence of two previously unidentified sinkholes and a major cavern system, the Wild Woman Cave Complex.

Electrical imaging method identified subsurface anomalies along the proposed access roads and at four of the six towers. The towers were moved away from the subsurface anomalies and the access roads were relocated to positions where subsurface anomalies would not pose a hazard to the heavy crawler cranes, used to erect the towers. The 50-tower Anadarko Mountain Wind Farm was successfully completed in 2016.

\section{Introduction}

Oklahoma ranks 8th for wind energy potential and maintains over 2,000 wind turbines in over 27 wind farms. As of 2016, Oklahoma has 3,134 megawatts of installed wind capacity (AWEA, 2017). Monies (2017) reported that as of 2017, Oklahoma had 6,600 megawatts of wind power that supply one quarter of Oklahoma's generated electricity.

The permitting process for a wind farm provides limited tower relocation potential without an extensive repermitting process; however, most permits provide for some limited relocation of a tower within an approximately $30 \mathrm{~m}$ radius of the tower without going through the repermitting process. Wind turbine towers consist, from the ground up, of the foundation, stalk, nacelle, and rotor blades. The foundation, in general, is a $15 \mathrm{~m}$ wide by $3 \mathrm{~m}$ deep steel-reinforced concrete subsurface slab. Unstable foundations can cause the towers to topple so the location of a stable foundation is critical to the installation of a tower.

The wind turbine towers are erected by crawler cranes that are slow $(1.4 \mathrm{~km} / \mathrm{hr}), 187 \mathrm{~m}$ tall, and very heavy with a ballast weight of approximately $600 \mathrm{t}$ (Liebherr, 2017). Crawler cranes are erected at a staging area and crawl to the individual towers for construction of the wind turbine towers. Further, crawler cranes due to their height can only tip up to $5^{\circ}$ from vertical before catastrophic collapse. Consequently, the road upon which the crane travels must be stable.

Areas with poor agricultural potential create ideal opportunities for wind power development, since the land is often remote and underutilized. One of these areas is located in the southern portion of the Arbuckle Mountains, eponymously named after General Matthew Arbuckle (1778-1851). The 6,000-hectare Arbuckle Mountain Wind Farm consists of 50 wind turbine generators that can produce $100 \mathrm{MW}$ of electricity. Construction of the wind farm was challenging due to the presence of karst topography within the steeply dipping beds of limestone and dolostone sediments (Figure 1). 
Caverns and passages at the site have been mapped by various grotto groups for decades and provided a useful characterization of the subsurface anomalies in the study area. For example, Harrel (1959) published a detailed cave map of Wild Woman Cave (Figure 2).

\section{Geology}

Arbuckle Mountain Wind Farm is situated in the western portion of the Arbuckle Mountains of south central Oklahoma (Figure 1). This portion of the Arbuckle Mountains is noted for having karst topography. The rock units consist predominantly of limestone, dolomite and rhyolite, with minor amounts of shale and sandstone. The carbonate units are characterized by having sinkholes, dolines, and caverns.

The rocks in this portion of the Arbuckle Mountains are part of the Arbuckle anticline and are contiguous with a south-dipping thrust fault, the Washita Valley Fault Zone (Johnson, 1990). The sediments at the wind farm site strike $\mathrm{N} 45^{\circ} \mathrm{W}$ and dip up to $45^{\circ} \mathrm{SW}$. Deformation or mountain building occurred during the Middle Pennsylvanian time and ended during the Late Pennsylvanian as flat-lying upper Pennsylvanian and Permian rocks overly the steeply inclined lower Pennsylvanian rocks in other areas nearby.
The predominant rocks of interest at the site are the karstforming limestones and dolostones. These carbonate rocks are estimated to be many thousands of feet thick (Ham, 1973). Surficial karst features observed in the field consisted of solution weathered vugs, bedding plane fractures, and voids.

Three geological groups lie within the footprint of the Arbuckle Wind Project. They are listed in order of decreasing age: middle Cambrian Colbert Rhyolite; upper Cambrian/lower Ordovician Arbuckle Group; and middle Ordovician Simpson Group.

The Colbert Rhyolite, located in the northern portion of wind farm, is a “...pink porphyritic rhyolite, locally flow-banded...” (Ham, 1951).

The Arbuckle Group contains 8 Formations, the Fort Sill Limestone, Royer Dolomite, Signal Mountain Formation, Butterly Dolomite, McKenzie Hill Formation, Cook Creek Formation, Kindblade Formation, and the West Spring Creek Formation. These formations are composed of limestone and dolomite with a maximum thickness of 2,000 $\mathrm{m}$ in the Arbuckle Mountain region (Ham, 1973). Thin sandstone beds are present within the
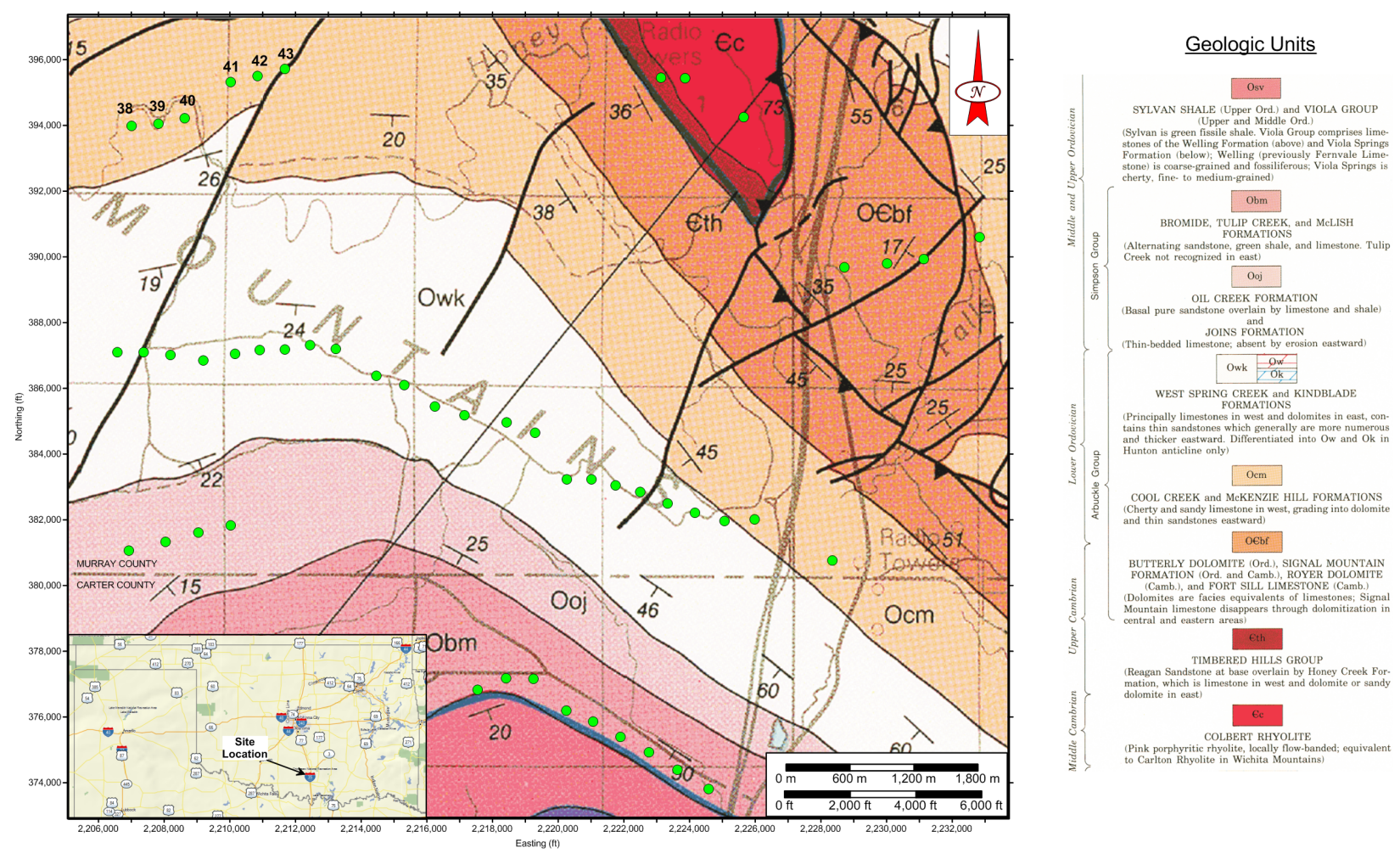

Figure 1. Geologic map of the western portion of the Arbuckle Mountains showing the locations of proposed wind turbine towers (green dots) to the Arbuckle Mountain Wind Farm (Johnson, 1990). 


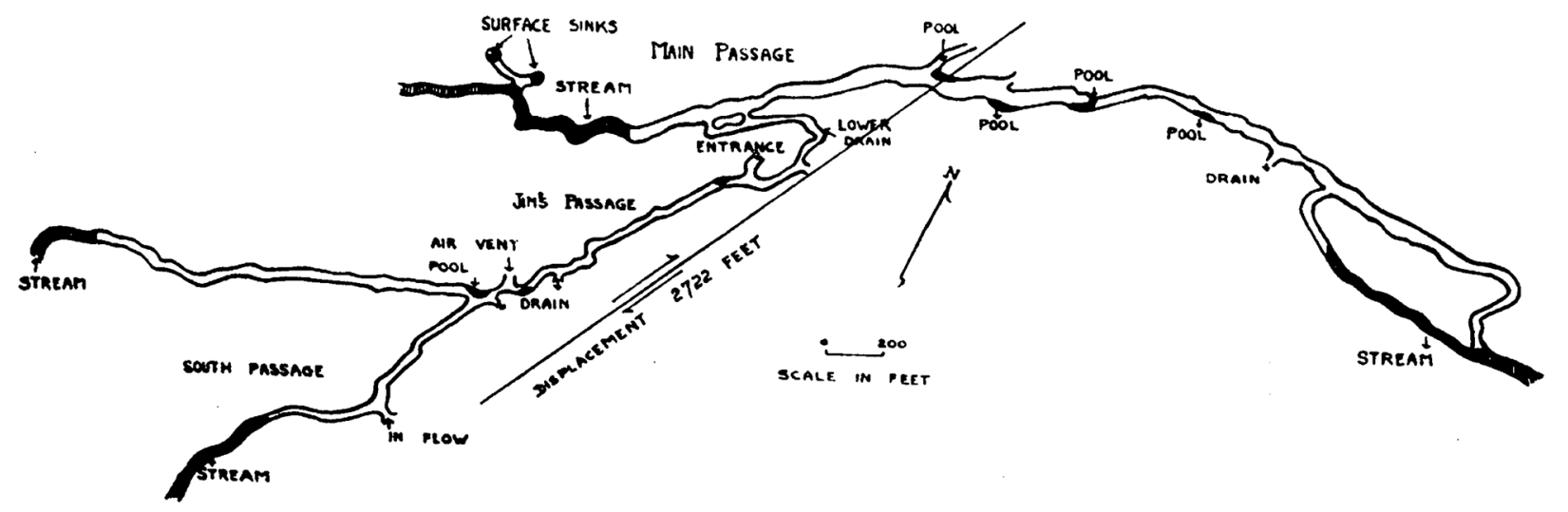

Figure 2. Subsurface plan map of Wild Woman Cave, Arbuckle Mountains (Harrel, 1959).

West Spring and Cool Creek Formations and cherty and sandy limestone is found throughout the Cool Creek and McKenzie Hill Formations.

The Simpson Group contains 5 Formations, the Joins, Oil Creek, McLish, Tulip Creek, and Bromide Formations. These units have a maximum thickness of $700 \mathrm{~m}$ in the Arbuckle Mountain region and are mainly comprised of limestone and dolomites with basal sandstones and minor amounts of shale (Ham, 1973).

During the formation of dolomite the net rock volume of limestone decreases leaving voids and vugs that can induce further dissolution. Klimchouk (2007; 2014) documents hypogene speleogenesis, or vertically upward migration of groundwater during the course of depositional history, as a mechanism for the creation of karst topography. Eschberger (2012) and Eschberger et al. (2014) noted hydrothermal intrusion during the Cambrian. Remanent magnetization of ferro-magnesium minerals during Pennsylvanian-Permian deformation has been attributed to the percolation of orogenic fluids through the carbonate units (Nick and Elmore, 1990). Sykes (1997) documented active basinal fluids during the Arbuckle and Laramide orogenies. Vertically upward flushing has continued to the present (for example, see Puckett, 2009; and Christensen et al., 2011). Blackwood (2017) and Blackwood et al. (2015) argued successfully that hypogenic flow created or initiated the dissolution processes, or speleogenesis, within the Arbuckle Mountains.

\section{Theory and Methods}

Electrical resistance is based upon Ohm's Law:

$$
R=V / I
$$

Where, resistance, $\mathrm{R}$ (Ohms), is equal to the ratio of potential, V (volts), to current flow, I (amperes). Resistivity, then, is a measure of the resistance $(\rho)$ along a linear distance $(L)$ of a material with a known crosssectional area $(A)$.

where $\quad \begin{array}{ll}R=\rho L / A ; \\ \rho=\frac{V}{I} \frac{A}{L}\end{array}$

Consequently, resistivity is measured in Ohm-meters and the data can be presented as a geo-electrical profile of modeled apparent resistivity versus depth.

Electrical currents propagate as a function of three material properties: (1) ohmic conductivity, (2) electrolytic conductivity, and (3) dielectric conductivity. Ohmic conductivity is a property exhibited by metals (Kaufman, 1992). Electrolytic conductivity is a function of the concentration of total dissolved solids and salts in the groundwater that exists in the pore spaces of a material (Reynolds, 1997). Dielectric conductivity is a function of the permittivity of the matrix of the material (von Hippel, 1954). Therefore, the matrix of most soil and bedrock is highly resistive. Of these three properties, electrolytic conductivity is the dominant material characteristic that influences the apparent resistivity values collected by this method (Milsom, 1989).

In general, resistivity values decrease in water-bearing rocks and soil with increasing: fractional volume of the rock occupied by groundwater; total dissolved solid and chloride content of the groundwater; permeability of the pore spaces; and, temperature.

Materials with minimal primary pore space (i.e., limestone, granite) or lack groundwater in the pore 
spaces will exhibit high resistivity values (Mooney, 1984). Highly porous, moist or saturated soil, such as fat clays, will exhibit very low resistivity values.

In homogeneous ground, the apparent resistivity is the true ground resistivity; however, in heterogeneous ground, the apparent resistivity represents a weighted average of all formations through which the current passes (Mooney, 1984). Many electrode placements (arrays) have been proposed (for examples, see Reynolds, 1997), including the most commonly deployed Wenner, Schlumberger, and dipole-dipole array. Two survey arrays, dipole-dipole and Schlumberger, were collected for each tomograph.

The Schlumberger array has proven to be an effective configuration for imaging the subsurface:

$$
R i=\pi a^{2} / b\left[1-b^{2} / 4 a^{2}\right] R ; a=5 b
$$

Where, resistivity $\left(R_{i}\right)$ is related the separation distance between the current source and current sink $(b)$, and the pole spacing, (a).

The dipole-dipole array collects a denser, deeper portion of the subsurface, and combined with the Schlumberger array, provides data for the construction of a detailed geo-electric profile. Dipole-dipole configuration is:

$$
R=\pi a n(n+1)(n+2)
$$

A forward modeling subroutine was used to calculate the apparent resistivity values for dipole-dipole and Schlumberger data sets, after which the data sets were combined using the EarthImager program (AGI, 2002). This program is based on the smoothness-constrained least-squares method (deGroot-Hedlin and Constable, 1990; Loke and Barker, 1996). The smoothnessconstrained least-squares method is based upon the following equation:

$$
J^{T} g=\left(J^{T} J+\mu F\right) d
$$

Where, $\mathrm{F}$ is a function of the horizontal and vertical flatness filter $(\mathrm{J})$ is the matrix of partial derivatives, $\mu$ is the damping factor, $\mathrm{d}$ is the model perturbation vector and $g$ is the discrepancy vector.

The EarthImager program divides the subsurface 2-D space into a number of rectangular blocks. Resistivities of each block are then calculated to produce an apparent resistivity pseudosection. The pseudosection is compared to the actual measurements for consistency. A measure of the difference is given by the root-mean-squared (rms) error.

\section{Discussion}

Since air (i.e., voids) and carbonate rock have very high apparent resistivity values it is difficult to distinguish between the two. Fortunately, most of the voids at the site, or at least those we could identify, contained clay and/or water; both of which have very low apparent resistivity values. For this site then, low apparent resistivity values and inversions (i.e., resistive material overlying conductive material) are considered to be indicators of weak rock conditions at depth with the possibility of the presence of vuggy subsurface conditions or voids.

Initially, paired electrical imaging profiles were collected at all 50 tower sites, which included (at the client's request) the three sites located on the Colbert Rhyolite (Figure 1). The possibility of a void in the Colbert, however, is remote and no subsurface anomalies were detected. The survey consisted of a pair of $69 \mathrm{~m}$ long lines set at right angles to each other. Each profile was centered at the staked locations of the proposed tower and imaged the subsurface geo-electric stratigraphy to a depth of approximately $18 \mathrm{~m}$ below grade.

Eighteen sites were determined to have potential subsurface anomalies (Table 1). All were relocated away from the subsurface anomalies and the new locations drilled to insure stable subsurface conditions. However, during this work, it was noted that the Main Access Road to Towers 38 through 43 crossed Wild Woman Cave Complex (Figure 3). This report documents the additional work that was performed to relocate the Main Access, East Access, and West Access Roads (Figures 4, 5,6 , and 7).

During the course of imaging the foundations at towers 38 through 43, several subsurface anomalies were noted (Table 1). Further, this area was considered to be a potential hazard for the crane. Profile 1 and $1 \mathrm{~A}$ through 1F; Profiles $2 \mathrm{~A}$ and $2 \mathrm{~B}$; and Profiles $3 \mathrm{~A}$ and $3 \mathrm{~B}$ were collected to assess the potential hazard to the heavy crane along the East and West Access Roads (Figures 4, 5 , and 6 , respectively). 


\begin{tabular}{|c|c|}
\hline Turbine & Formation \\
\hline 16 & \multirow{10}{*}{ West Spring and Kindblade } \\
\hline 17 & \\
\hline 22 & \\
\hline 26 & \\
\hline 27 & \\
\hline 28 & \\
\hline 29 & \\
\hline 30 & \\
\hline 31 & \\
\hline 33 & \\
\hline 40 & \multirow{5}{*}{ Cool Creek and McKenzie Hill } \\
\hline 41 & \\
\hline 42 & \\
\hline 43 & \\
\hline 50 & \\
\hline 47 & \multirow{3}{*}{ Butterly, Signal Mountain, Royer \& Fort Sill } \\
\hline 48 & \\
\hline 49 & \\
\hline
\end{tabular}

Table 1. Table of towers with El identified
From the previous study, subsurface anomalies were noted at Towers 41, 42, and 43 (Table 1). Profile 1 and cross lines $1 \mathrm{~A}$ through $1 \mathrm{~F}$ show the presence of numerous subsurface anomalies along the proposed crane path (Figure 4). Due to the potential risk to the the towers and crane, Towers 41,42 , and 43 and the portion of the East Access Road between the towers were relocated approximately $20 \mathrm{~m}$ to the south (Figure 8).

The southern portion of the East Access Road was inferred to cross Persimmon Cave. Two profiles; Profile 2A and 2B, were collected in the area to determine if any subsurface anomalies existed (Figure 5). Persimmon Cave is inferred to exist at depth at position $460 \mathrm{ft}(140 \mathrm{~m})$ on Profile 2A. There is approximately $8 \mathrm{~m}$ of interpreted hard rock overlying the inferred cave (Figure 5). Due to the interpreted size and depth of the cave, the proposed location of the East Access Road that crossed over the inferred location of Persimmon Cave was not interpreted to be a hazard to the crane and the road was not relocated (Figure 8). anomalies.

Figure 3. Topographic map (contour

interval 2 feet; $0.6 \mathrm{~m}$ ) showing the originally proposed roads and the electrical imaging profile locations. The location of the Wild Woman Complex is from Curtis (1959) and the sinkhole locations are from Blackwood (2014). Location of Persimmon Cave is approximated and is not based upon real information. Map scale is set to Oklahoma State plane coordinate system, NAD 1983, in feet.

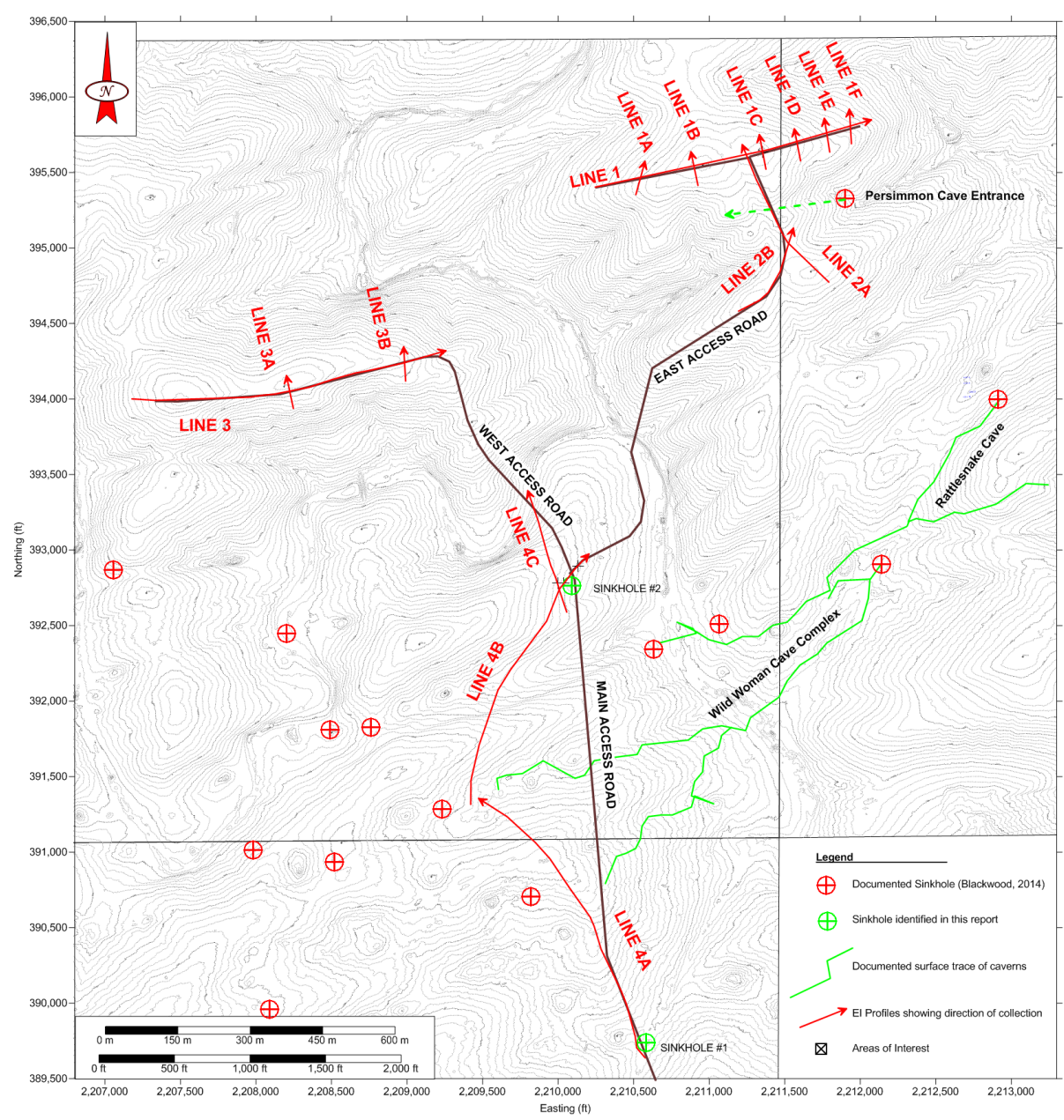




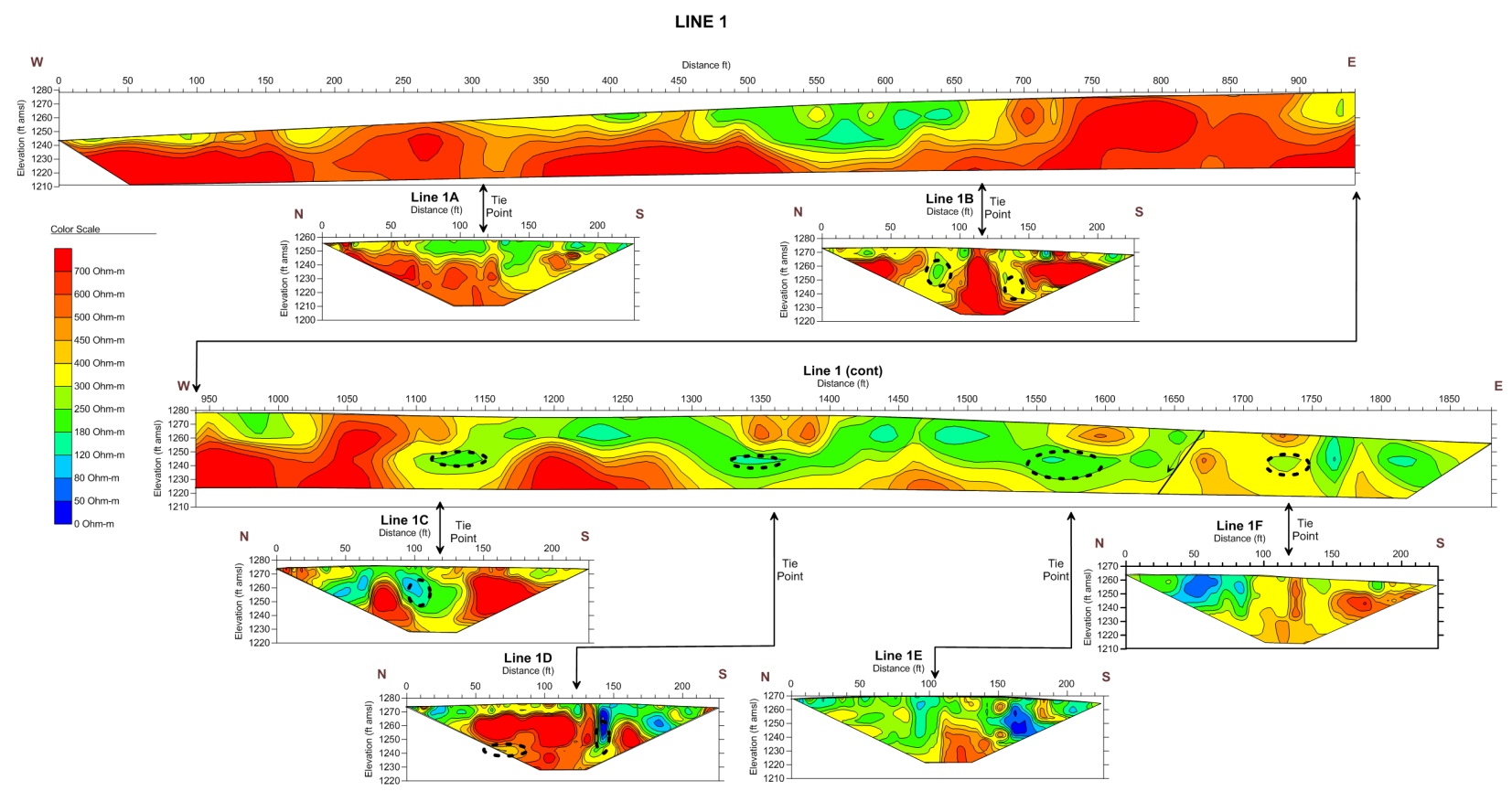

Figure 4. Profile Line 1 and cross Profile Lines IA through IF. Color scale shown is used on all figures but only reproduced here. Profiles have no vertical exaggeration. Subsurface anomalies are noted with dashed black ovals.

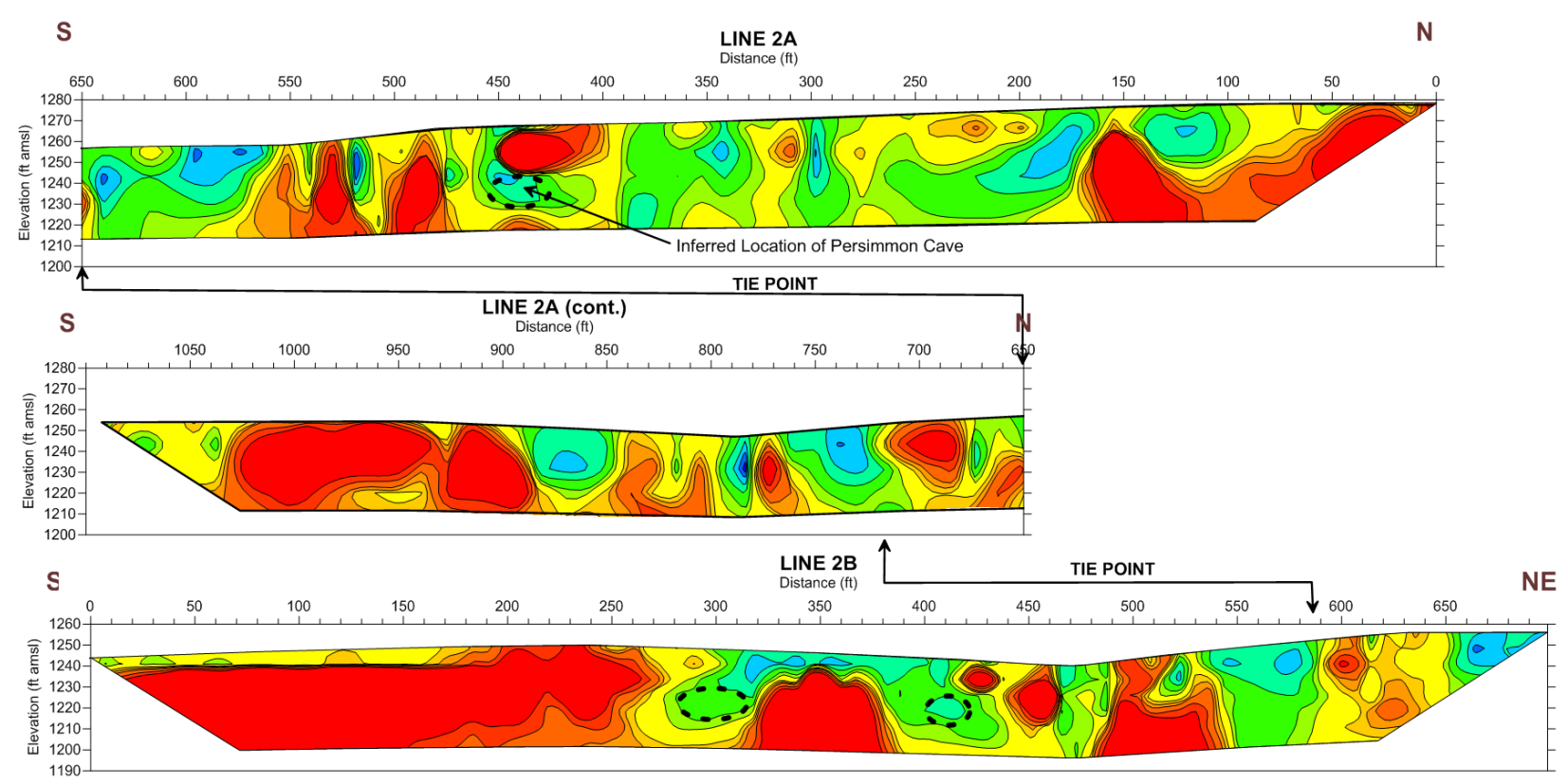

Figure 5. Profile Line 2A and 2B. Color scale from Figure 4. Profiles have no vertical exaggeration. Subsurface anomalies are noted with dashed circular black lines. 


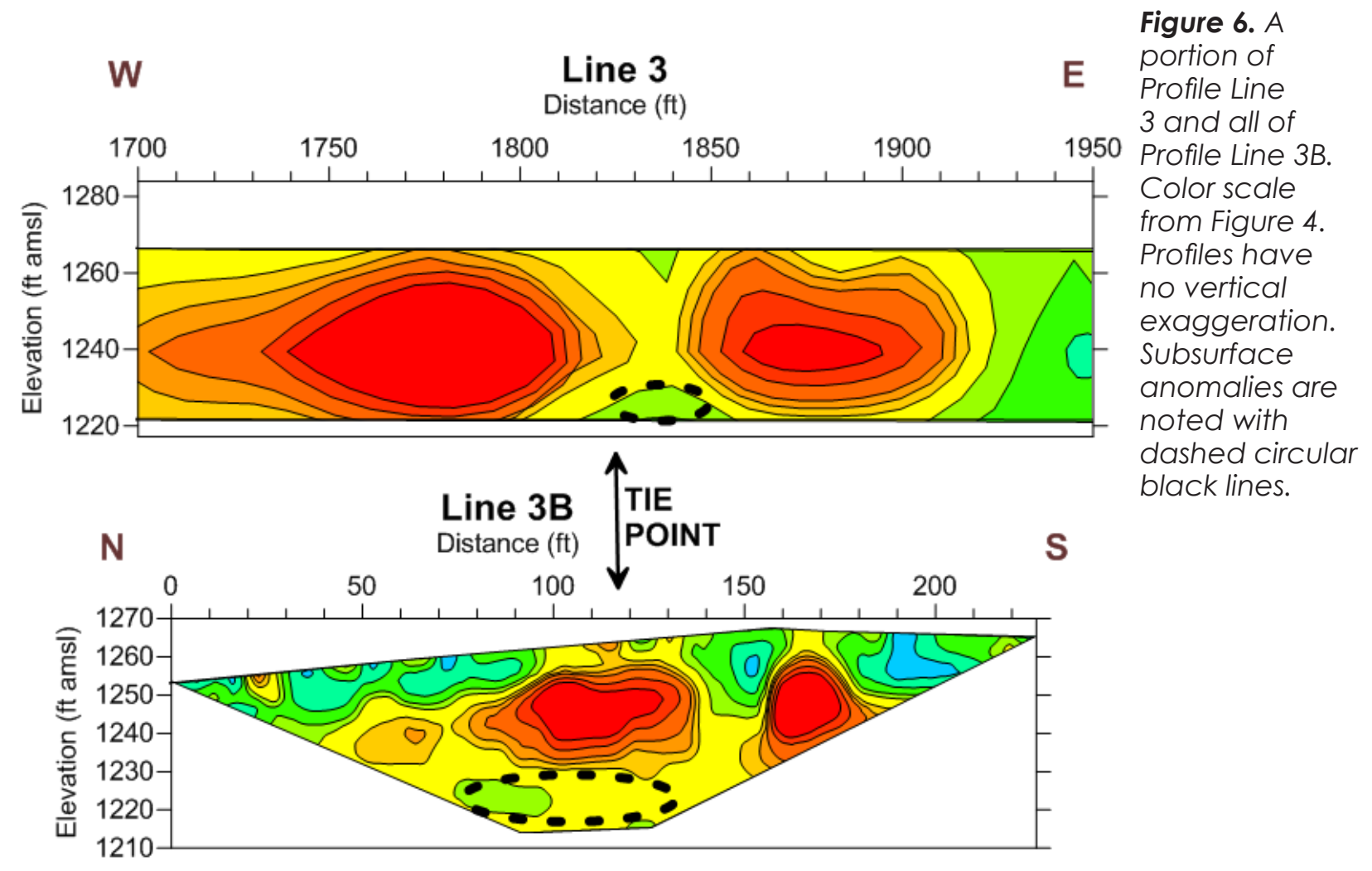

Figure 7. Portion of Profile Line $4 A, 4 B$, and $4 C$. Color scale from Figure 4. Profiles have no vertical exaggeration. Subsurface anomalies are noted with dashed circular black lines.
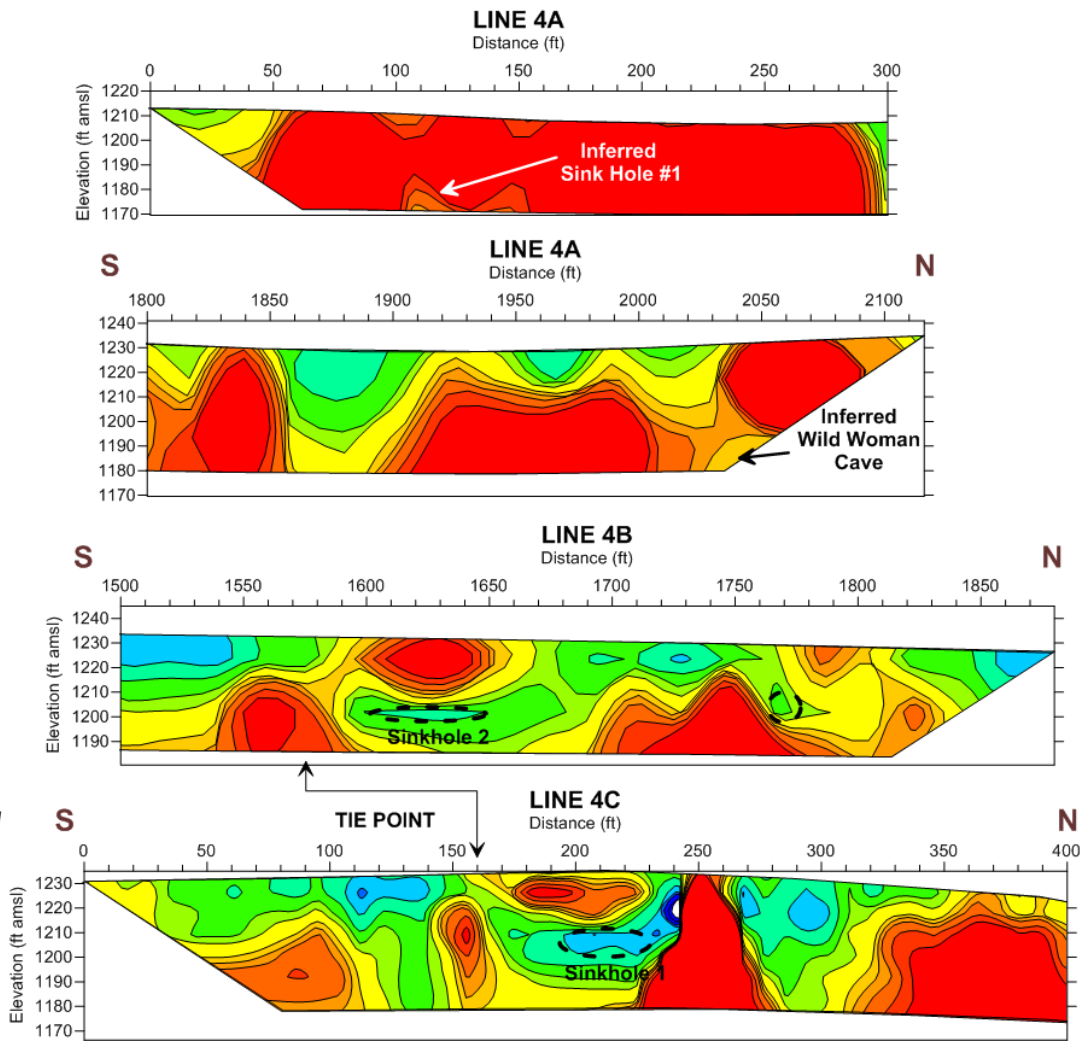
Further south along the East Access Road to Towers 41 through 43 , two subsurface anomalies were determined to be enough of a hazard to warrant relocation of the crane path (Figures 5 and 8 ). The crane path was moved 6 to $10 \mathrm{~m}$ southeast of the proposed path to avoid any subsurface issues (Figure 8).

The West Access Road to Towers 38 through 40 showed only one subsurface anomaly at a depth of $10 \mathrm{~m}$ below grade (Figure 6). Due to its interpreted size and depth, this anomaly was not considered to be a hazard to the crane. It should be noted that Tower 40 was moved $10 \mathrm{~m}$ to the west to avoid a subsurface anomaly.

The Main Access Road to the six towers crossed portions of Wild Woman Cave Complex, that necessitated the relocation of the road (Figure 3). At the southern end of the road, Sinkhole \#1 was discovered along the proposed

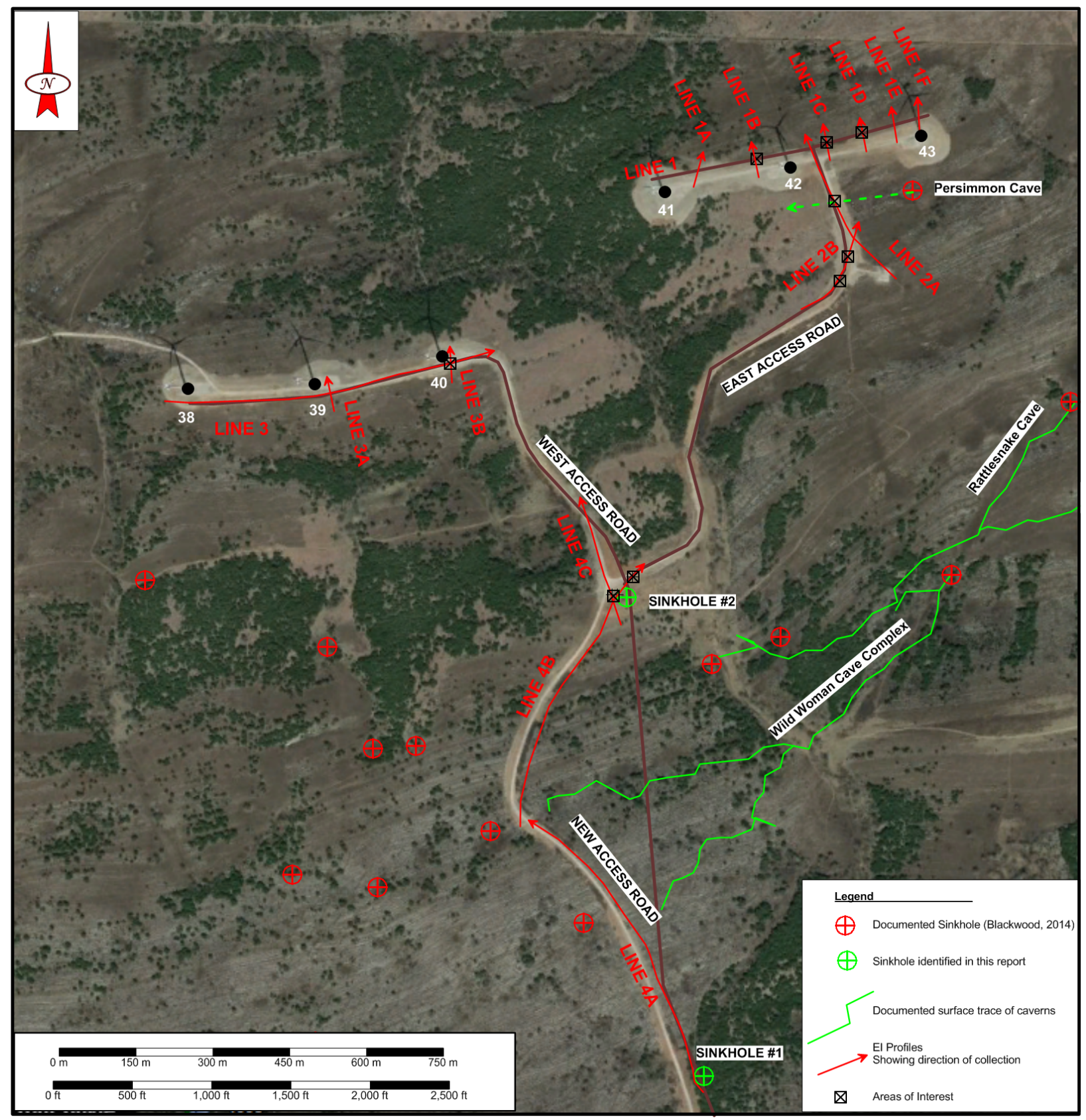

Figure 8. Aerial map of Anadarko Mountain Wind Farm showing tower locations (black dots) and as-built access roads (Google Earth, 2017). 
road. Profile $4 \mathrm{~A}$ at position $115 \mathrm{ft}(35 \mathrm{~m})$ shows an anomaly inferred to be this sinkhole (Figure 7). Profile 4A may have imaged Wild Woman Cave (position 2,050 ft; $630 \mathrm{~m}$ ) at a depth of approximately $14 \mathrm{~m}$ below grade. Further, Profile 4B and 4C imaged Sinkhole \#2 at a depth of approximately $8 \mathrm{~m}$ below grade. A small anomaly interpreted to be a cavern is located on Profile $4 \mathrm{~B}$ at position $1,770 \mathrm{ft}(540 \mathrm{~m})$.

Wild Woman Cave was not considered to be a hazard to the crane as the cave was interpreted to be located at a depth too deep to impact the crane. The Main Access Road, now termed the New Access Road, was rerouted around Sinkhole \#2. Further, the interpreted anomaly at the end of Profile 4B was interpreted to pose a hazard to the crane and the beginning of the East Access Road was moved north approximately $10 \mathrm{~m}$ to avoid the void.

The wind farm was installed successfully without any delays or problems. Consequently, electrical imaging methods are an effective method of identifying subsurface anomalies that pose a risk to engineered facilities.

\section{References}

AGI. 2002. EarthImager Program. American

Geosciences Inc., Austin Texas.

AWEA. 2017. American Wind Energy Association: Washington, DC.

Blackwood KW. 2014. Wild Woman Cave: Preliminary Spatial Analysis. Unpublished document.

Blackwood KW, Halihan T, Beard K. 2015. Development and distribution of hypogene caves and paleokarst features in the Arbuckle Mountains of South Central Oklahoma, USA. Abs. AAPG Annual Convention, Denver, Colorado.

Blackwood KW. 2017. Hypogenic Caves and Paleokarst of the Arbuckle Mountains, Oklahoma. In: Klimchouk AB, Palmer A, De Waele J, Auler A, Audra P, editors. Hypogene Karst Regions and Caves of the World. Cave and Karst Systems of the World. Springer, Cham. p. 653-661.

Christensen S, Osborn NI, Neel CR, Faith JR, Blome CD, Puckett J, Pantea MP. 2011. Hydrogeology and simulation of groundwater flow in the Arbuckle-Simpson aquifer, south-central Oklahoma. U.S. Geological Survey Scientific Investigations Report 2011-5029. p. 18-98.

Harrel R. 1959. A preliminary report on the invertebrate animals of Wild Woman Cave. Proceedings of the Oklahoma Academy of Sciences, 40: 20-31.
Degroot-Hedlin C, Constable S. 1990. Occam's inversion to generate smooth, two-dimensional models from magnetotelluric data. Geophysics 55 (12): 1613-1624.

Elmore RD. 2001. A review of paleomagnetic data on the timing and origin of multiple fluid-flow events in the Arbuckle Mountains, Southern Oklahoma. Petroleum Geoscience 7 (3): 223-229.

Eschberger AM, Hanson RE, Puckett RE. 2014. Carlton Rhyolite Group and Diabase Intrusions in the East Timbered Hills, Arbuckle Mountains. In: Suneson NH editor. Oklahoma Geological Survey. Guidebook 38: 143-186.

Eschberger AM. 2012. Volcanological and geochemical studies of Cambrian rift-related igneous rocks in the western Arbuckle Mountains, southern Oklahoma [Master's Thesis]. Texas Christian University, Fort Worth, Texas.

Google Earth. 2017. Google Earth aerial photographic program. San Francisco (CA). Google.

Ham WE. 1951. Geology and petrology of the Arbuckle limestone in the southern Arbuckle Mountains, Oklahoma [PhD Dissertation]. Yale Univ.

Ham WE. 1973. Regional geology of the Arbuckle Mountains, Oklahoma. Oklahoma Geological Survey Special Publication 1.

Johnson KS. 1990. Geologic Map and Sections of the Arbuckle Mountains, Oklahoma; Circular 91, Plate 1 of 2, Oklahoma Geologic Survey; revised from Ham WE, Mckinley ME, et al. 1954.

Kaufman AA. 1992. Geophysical Field Theory and Method: Gravitational, Electric, and Magnetic Fields. New York (NY): Academic Press.

Kharaka Y, Law L, Carothers W, Goerlitz D. 1986. Role of organic species dissolved in formation water from sedimentary basins in mineral diagenesis. In: Gautier DL, editor. Roles of organic matter in sediment diagenesis. Society of Economic Paleontologists and Mineralogists, Special Publication 38: 111-122.

Klimchouk AB. 2007. Hypogene speleogenesis: hydrogeological and morphogenetic perspective. National Cave and Karst Research Institute, Carlsbad, New Mexico. p. 5-97.

Klimchouk AB. 2014. The methodological strength of the hydrogeological approach to distinguishing hypogene speleogenesis. Hypogene Cave Morphologies Special Publication. National Cave and Karst Research Institute, Carlsbad, New Mexico.

Liebherr. 2017. Crawler Crane Specifications. LiebherrInternational AG self-published brochure.

Loke MH, Barker RD. 1996. Rapid least-squares inversion of apparent resistivity pseudosections by a quasi-Newton 
method. Geophysical Prospecting 44 (1): 131-152.

Milsom J. 1989. Field Geophysics. New York (NY). Halstead Press.

Monies P. 2017. Oklahoma governor signs bills to end wind incentive, airfield loophole. 18 April 2017. Oklahoma City (OK). The Oklahoman.

Mooney HM. 1984. Handbook of Engineering Geophysics. Minneapolis (MN). Bison Instruments, Inc.

Nick KE, Elmore RD. 1990. Paleomagnetism of the Cambrian Royer Dolomite and Pennsylvanian Collings Ranch Conglomerate, southern Oklahoma: an early Paleozoic magnetization and non-pervasive remagnetization by weathering. Geological Society of America Bulletin, V102. p. 1517-1525.

Puckette JT, Halihan T, Faith J. 2009. Characterization of the Arbuckle-Simpson Aquifer-Final Report for the Arbuckle-Simpson hydrology study. Stillwater (OK). Oklahoma State University, School of Geology, for the Oklahoma Water Resources Board.

Reynolds J. 1997. An introduction to applied and environmental geophysics. New York (NY). John Wiley \& Sons.

Sykes M. 1997. Paleokarst characteristics of the surface and subsurface in the Viola Limestone (Ordovician), Arbuckle Mountains. Shale Shaker. Oklahoma City Geological Society. Oklahoma (OK). 47: 107-121.

Von Hippel AR. 1954. Theory. Von Hippel AR. Editor. Dielectric Materials and Applications. Cambridge (MA). The MIT Press. 